\title{
Broadening Minds: Exploring Intercultural Understanding in Adult EFL Learners
}

Ferney Cruz Arcila

\begin{abstract}
Our current globalized world has become a space where many cultures are in permanent contact. Now, we are living in an interconnected world that requires us to be tolerant with others. This article describes some processes through which adult EFL learners developed intercultural understanding. This research aimed to provide clear examples of how significant and necessary it is to give foreign language learners the chance to become aware of the foreign culture while they are becoming proficient in the target language. In addition, this paper also accounts for some kinds of intercultural connections the students make between their native culture and the target one. Through a careful analysis of the data collected, this qualitative case study shows that by implementing different types of pedagogical strategies the students are able to go beyond superficial ideas about the target culture which help them become more open-minded towards other forms of perceiving reality.
\end{abstract}

Key words: Culture, intercultural understanding, cultural identity, cultural stereotype.

\section{Resumen}

El mundo actual se ha convertido en un espacio en el que muchas culturas están en contacto permanente. Hoy en día vivimos en un mundo interconectado que nos demanda ser tolerantes con los demás. Este articulo describe algunos procesos por medio de los cuales estudiantes adultos de inglés como lengua extranjera desarrollan un entendimiento intercultural. La investigación aquí descrita provee claros ejemplos de lo significativo y necesario que es el hecho de darle a los aprendices de lenguas extranjeras la oportunidad de tomar conciencia de la cultura extranjera mientras se están volviendo proficientes en la lengua objetivo. Además, este articulo describe algunos tipos de conexiones interculturales que los estudiantes hacen entre su cultura nativa y la cultura objetivo. A través de un cuidadoso análisis de los datos recogidos, este estudio de caso muestra que al implementar diferentes tipos de estrategias pedagógicas los estudiantes son capaces de ir mas allá de las ideas superficiales que tienen sobre la cultura objetivo. Esto a su vez los ayuda a volverse mas abiertos hacia otras formas de percibir la realidad.

Palabras Claves: cultura, entendimiento intercultural, identidad cultural, estereotipo cultural.

\footnotetext{
* Received: 02-02-07/Accepted 09-08-07
} 


\section{Introduction}

Currently we are moving in contexts that require that we be culturally competent to act, not only in our own cultural conditions, but also in those of others. It is, thus, important that language learners and teachers start to broaden their minds by including in their practices room to reach an awareness of the different culture or cultures they are exposed to by means of the target language. Teachers should help students have insights and understanding of different ways of behaving, doing things and perceiving reality. This research study attempted to describe the manner in which adult EFL learners perceive other ways of behavior different to their own and the ways in which this affects their own identity, through the use of different pedagogical activities, such as small group discussions, role plays, presentations and a movie.

First of all, in this paper I will begin with a description of the problem. Secondly, I will discuss the main theoretical constructs of the research such as culture, intercultural understanding and cultural stereotype among others. Thirdly, I will focus on the methodology followed in this study. Finally I will present findings and conclusions.

\section{Theoretical Backbone of the Study}

One of the most important goals for EFL learners is to become bilingual. However, there is a tendency to think that being bilingual refers merely to the ability to speak two languages or to master two linguistic codes. This is a very narrow vision of what the fact of being bilingual entails. Walsh (1991), adopting a critical position, refers to bilingualism as "the ability to not just speak two languages, but to be conscious of the socio-cultural, political, and ideological contexts in which the languages (and therefore the speakers) are positioned and function, and the multiple meanings that are fostered in each"(p.127 as cited by Pennycook 2001).

Considering Walsh's idea we can see how broad teaching and learning English could be, besides that, we can realize how important it is for EFL learners and teacher to go beyond the simple mastering of linguistic skills. We both teachers and learners should be involved in a getting aware of the foreign contexts while being engaged in studying or teaching a language.

In particular, this study accounts for the need students have to be acquainted with the target language culture. The idea that underpins this study, 
however, is not to foster students to adulate the foreign culture but on the contrary to adopt a "resistance perpective" Canagarajah (1999), which claims for the "possibility that in everyday life, the powerless in post colonial communities may find ways to negotiate, alter, and oppose political structures and reconstruct their languages, cultures and identities to their advantage" (pg. 2).

\title{
Culture
}

To provide a description of what culture entails is difficult. There are a variety of different definitions which attempt to convey what the concept means from different perspectives. A general definition of what is frequently understood by culture is provided by Richards et al (1999) "culture is the total set of beliefs, attitudes, customs, behavior, social habits, etc. of the members of a particular society" (p.94). From this broad definition we can see the different kinds of perspectives from which culture can be viewed. Many emphasize beliefs, others behavior, others habits or customs of a specific group of people and provide their own definition. In this study, culture is understood, not only as behavior, customs or beliefs, but also as attitudes and insights people usually reveal when they develop socio-cultural competence (Byram, 1990). In this sense, the concept adopted in this study is closely related to Cortazzi \& Jin's (1999) vision of culture. For them:

\begin{abstract}
"...Culture can be seen as the framework of assumptions, ideas and beliefs that are used to interpret other people's actions, words and patterns of thinking. This framework is necessarily subjective and is commonly taken for granted. However it is crucial that foreign language learners should become aware of different cultural frameworks, both their own and those of others; otherwise they will use their own cultural system to interpret target language messages whose intended meaning may well be predicated on quite different cultural assumptions". ( $p, 197)$
\end{abstract}

We usually tend to perceive our own culture as the appropriate way of looking at and doing things, and of perceiving reality. This is what happens when we learn a foreign language. We tend to adapt the new language to our cultural patterns without considering the different cultural implications involved. Sometimes, neither students nor teachers are really conscious of the cultural aspects of language learning and teaching. We may be speakers of a language but still not be "intercultural speakers" (Roberts et al 2001; Kramsch, 2002). Byram (1998) gives an account of different ways through which intercultural competence can be developed, such as: 


\begin{abstract}
"A comparative analysis in pedagogically-appropriate ways of how different languages express different cultures, understanding by the teacher of ways in which the explicit introduction of cultural elements from other cultures relativises and challenges what is taken for granted in the international or state curriculum; and that teachers should develop 'intercultural speakers intuitions' “ ( $p, 113)$ as cited by de Mejia (2002).
\end{abstract}

It is now broadly accepted that learning a foreign language does not mean simply mastering an object of academic study but is more appropriately focused on learning a means of communication. Communication in real situations is never out of context, and because culture is part of most contexts, communication is rarely culture-free. (Cortazzi $\mathcal{E}$ Jin in Hinkel 1999). The inevitably fact of teaching culture when teaching language, which has been highlighted in this study, leads us to think that culture plays a more important role in language teaching and learning than often recognized.

\title{
Intercultural, Cross-cultural and Multicultural Communication
}

When talking about the communicative and social relationships between the EFL learners' own culture and language in relation to the foreign language and culture, it is necessary to distinguish different types of mediations that come about. These mediations can be of a cross-cultural, an intercultural or a multicultural nature. Kramsch (1998) explained what is commonly understood by these terms. She said that the terms "cross-cultural" or "intercultural" refer to the meeting of two cultures or two languages across the political boundaries of nation states. In other words, cross-cultural communication takes place between cultures and languages from different countries and culture shock is likely to result. She also highlighted the fact that the term "multicultural" also refers to communication between people from different ethnic, social, gendered cultures within the boundaries of the same national language. Besides that, the term may also be used to refer to the dialog between minority cultures and dominant cultures and has to do with issues related to bilingualism and biculturalism.

Kramsch also stated that the term "multicultural" can be used in two ways. In a societal sense and in an individual sense. With regards to society, the term indicates the coexistence of people from many different backgrounds and ethnicities. With regards to the individual, the term characterizes people who belong to various discourse communities and who therefore have the linguistic resources and social strategies to affiliate and identify with many different cultures and ways of using the language. 


\section{Intercultural Understanding}

Most of the foreign language learning models that have emerged have concentrated mainly on the descriptive study of the linguistic elements of the language, without considering the fact that contact with the foreign culture is implicit in the target language. Consequently, students will probably face difficulties in interacting using the target language in foreign cultural conditions and contexts.

Models and theories such as Skinner's (1953) Behaviorism (learning through habit formation), Chomsky's (1968) Cognitive Theory (learning as a process in which the learner actively tries to make sense of data), and Krashen's (1982) Creative Construction Theory (language learning takes place through the learner's internal representation of the target language) have mainly dealt with a range of factors related to the development of the target language that take into consideration the learner's own context. These theories often disregard and ignore the importance of helping language learners to become interculturally competent through understanding and knowing how the culture of the target language works.

Currently, we are facing many instances of cultural contact that may lead to situations of conflict if we are not prepared to deal with this. Nowadays, language learners need to be provided, not only with linguistic tools, but also with cultural knowledge for them to be prepared for intercultural communication. Savignon \& Sysoyev (2002) explain that,

\footnotetext{
"from the perspective of socio-cultural education, efficient and successful intercultural communication comes about only when learners assume their roles, both as openminded representatives of their L1 community and as subjects engaged in a dialog of cultures" (p.3).
}

They agree with Brown's (1994) idea of adopting a positive and open-minded attitude towards cross-cultural differences by understanding and recognizing different worldviews. Brown also states that a closed view of such differences often results in the maintenance of stereotypes, involving an oversimplification and blanket assumptions about the foreign culture. In this sense, teachers need to be able to provide students with linguistic aspects and with cultural understanding that help learners develop intercultural awareness and competence through which they will be able to achieve instrumental, social goals and appropriateness, such as suitable communication in a given situation in a particular culture (Martin 1993 as cited by Cortazzi $\mathcal{E}$ Jin, 1999). 
Cultural understanding and awareness mean being aware of the members of another cultural group: their behavior, their expectations, their perspectives and values. It also means attempting to understand their reasons for their actions and beliefs (Ibid). Cultural understanding, thus, may be reached based on a set of cultural universals that allow us to accept other perceptions of reality different from our own. Murdock (1961), as cited by Brown (1994) gives an account of seven universals of cultural behaviors as follows: 1) they originate in the human mind, 2) they facilitate human and environmental interactions; 3) they satisfy basic human needs; 4 ) they are cumulative and adjust to changes in external and internal conditions; 5) they tend to form a consistent structure; 6) they are learnt and shared by all the members of a society; and 7) they are transmitted to new generations.

\section{Cultural Stereotypes}

Our perception of someone's social identity is very much culturally determined. What we perceive about a person's culture and language is what we have been conditioned by our own culture to see, and the stereotypical models already built around our own, (Kramsch, 1998). The stereotyped vision of culture people usually have, as described by Kramsch, is highly related to and conditioned by our own culture. The members of a particular cultural community have been conditioned to identify themselves as belonging to that community, either because they speak the language of the community, or because they are from the same region or country.

Samacá (2002) has explained that we have the tendency to build an oversimplified image of the other culture from our own vision of the world. He points out that this fact makes us see very exaggerated cultural differences, which, in turn, lead us to build stereotyped cultural features of others. On the other hand, he states that despite the fact that cultural stereotype is seen as a negative phenomenon; it can be used to make a language learner more knowledgeable towards the other culture as well. According to him, by deeply analyzing stereotypes of the target language culture in the classroom, the learner obtains a certain level of cultural competence that allows him to be aware of features implicit in the target culture.

From my point of view and considering the above, cultural stereotypes are unavoidable simplified visions of the foreign culture that we tend to construct based on our own cultural identity and the vision of the world we have. Usually, 
the stereotypes we have tend to be negative, since they are the product of taking into consideration just a few features of the foreign culture. However, as in this study, stereotypes can be positively used to help the learner get to know the other culture by analyzing the stereotype and discovering that it is necessary to go beyond these simplified visions.

\section{Cultural Identity}

In most cases, language learners see themselves benefiting from an increasing awareness of cultural practices different from their own. They usually become more open minded and tolerant to dissimilar ways of doing and perceiving things. However, the influence of having contact with foreign cultural realities may also have a negative impact on the learners' own identity. Even though research has shown that most learners react positively towards cross-cultural contact in the classroom and other settings, it has also been acknowledged that some people may experience psychological blocks and other inhibiting effects of contact with second language culture, (Brown, 1994). In this case, it is necessary for the students to be provided with tools to help them overcome cultural alienation in second language learning (Stevick, 1976). Donahue and Parsons (1982 as cited by Brown, 2000) examined the use of role-play in the language classrooms as a tool to help students succeed in cultural understanding. They explained that the use of role-plays is very useful to promote the process of cultural dialog in language learning, while, at the same time, it provides opportunities for oral communication. Brown also mentions techniques such as, reading, films, and simulation games as ways of aiding the students to have a positive vision of the foreign culture.

Furthermore, the alienation phenomenon experienced by some individuals also makes us think that it is possible to see that the contact of cultural identities results in shock. In this regard, Kramsch (1998) points out that "despite the entrenched belief in the one language = one culture equation, individuals assume several collective identities that are likely not only to change in time over dialog with others, but are liable to be in conflict with one another" ( $p, 67)$.

Kramsch's words also highlight two important elements that come into play when being engaged in a process of cultural understanding, namely time and change. Through time, the initial cultural identity will change and be modified according to the new intercultural experiences. In this aspect, de Mejia (2002) also emphasizes "the development of cultural understanding is part of a process that necessarily takes time, involves change and is produced and reproduced through everyday practices in cycles of interaction. Thus, culture is not, as is sometimes maintained, a possession 
of individuals, a tradition, which is transmitted by a society to be handed down and learned by its members" ( $p, 54)$.

To sum up, the present cross-cultural contexts in which we all interact have created the need for becoming interculturally competent. Nowadays, it is not just a matter of knowing the foreign language that can enable us to successfully interact in foreign cultural contexts and conditions; it is also a matter of being open minded to different ways of behaving and perceiving reality. We have to broaden our horizons and understand dissimilar ways of conceiving and doing things. In this sense, language teaching should provide spaces for learners to deepen insights into the culture that is implicit in the language they are taught. Research has shown that in so doing, people develop a capacity to deal with subsequent cultural differences when interacting in alien conditions.

\section{Methodology}

In particular, this qualitative case study aimed at understanding the ways in which EFL learners may raise intercultural understanding and the ways in which this understanding may affect their own cultural identity. I wanted to analyze in depth the processes through which learners develop intercultural understanding and how this understanding of other cultures might influence their own concept of cultural identity. To do so, this research was underpinned by the following main question: How do adult EFL learners reveal their understanding of intercultural aspects of their culture and the English speaking cultures?

\section{Setting and Participants}

This research project took place at Extension courses program of Universidad Pedagógica Nacional (UPN). The UPN is a public university, which mostly offers opportunities for people to become teachers in different areas of education, such as Technology, Sciences and Humanities.

The participants in this study were seven adult students whose ages ranged from 25 to 50 years old. They were enrolled in the Extension courses program of UPN and were classified as being at an intermediate proficiency level of English. They were interested in dealing with cultural issues, in addition to learning English as a foreign language. In general, the participants were from upper middle social backgrounds; five were professionals in different fields, such as accounting, law, psychology and international business. The other two participants had different jobs. In general, their main interests in studying 
English focused on increasing their opportunities in their jobs, getting promoted, doing better at the university, traveling and for personal growth.

\section{Procedures and Instruments of Data Collection}

In order to gather data, I used the following instruments: questionnaires, videotapes, reflective journals and interviews.

Questionnaire: This was the first instrument I used. It was an open-ended questionnaire aimed at obtaining information about the participants' first insights regarding the cultures of English speaking countries and their own culture. It was divided into two parts. The first section aimed at exploring the participants' general or specific ideas about the target cultures. The second was more related to Colombian culture as such. On the whole, the first part of the questionnaire had questions about general, positive and negative aspects of the foreign culture as well as aspects the participants would like to investigate in more depth. In the second part of the questionnaire, the participants were asked to describe their own culture and to give reasons why they felt identified or not with it (see Appendix 1). My idea of using a questionnaire to gather the information described above is supported by Lankshear $\&$ Knobel (2004). They see questionnaires as a helpful tool to identify participants' trends or preferences.

Videotapes: I found it useful to have videotaping in my research plan, since this provided me with the opportunity to capture both verbal and nonverbal interactions of the entire group of participants that took place in every group discussion regarding my topic of interest. According to Hopkins (1995) this instrument is a means of gathering general information about a specific phenomenon, which was my interest. Likewise, behavioral patterns relevant to the project could be identified. Furthermore, this instrument allowed me to keep a very detailed and systematic record of every participant.

Participants' journal: The data from the participants' journals have provided me with evidence of personal impressions on intercultural issues discussed in class from each participant's perspective, which has given me important insights and provided alternative perspectives of the cultural issues we were concentrated on (see Appendix 2). As Hubbard \& Miller (1993) put it, participants' journals have allowed me to have a clear picture of their reactions, perceptions, reflections and thoughts. I decided to use this instrument as a 
complement to the videotaped class sessions since it provided me with more personal and valuable insights regarding the cultural topic presented, which in many cases were not expressed during the discussion.

Interviews: I decided to conduct semi-structured interviews as described by Nunan (2001). In this kind of interviews, I, as a researcher, exercised the minimum degree of control possible and the course of the interview was led by the interviewee's responses. The interviewee was free to speak and express his/ her thoughts. The main interest I had in using this tool was to learn more about the subjects of study, their perceptions of cultural differences or similarities between English speaking countries and Colombia, their reflections, their remarks, their needs and the like (see Appendix 3). In this fashion, I used the data collected by means of the other instruments to go beyond, to check my interpretations, to ask for clarification and to expand on the participants' ideas and opinions. In order to avoid bias, I followed Seidman's (1991) suggestions, so while interviewing I tried to minimize as much as possible my influence on the interviewee, I tried to ensure that it was a participant meaning making process, rather than one dominated by the researcher.

\section{Pedagogical Intervention}

Throughout this paper I have stated that my main interest in this project was to study ways in which adult EFL learners' cultural understanding is revealed and ways in which this affects their own cultural identity. To do so, I decided to analyze this phenomenon by involving the participants in different types of discussions that allowed them to react freely towards cultural issues of some English speaking countries they themselves chose to talk about (USA, Canada, UK, Australia). Thus, the participants in this project were able to recognize how tolerant with and aware of other cultures they were. One of my roles as a participant observer was to provide the participants with a variety of activities that culminated in holding group discussions on the cultural issues each participant was focused on. Among the activities I brought to the classroom were: a movie, explicit discussions on cultural similarities and differences and role-plays aimed at setting students in foreign cultural situations.

A movie: At the beginning of this study and in order to contextualize the students and motivate them to inquire about cultural issues, I arranged for the participants to get into contact with the foreign culture through a movie that heavily illustrates cultural aspects. This movie is called "My big fat Greek 
wedding". This movie portrays the kinds of cultural conflicts in a very traditional Greek family when a Greek woman falls in love with a man that belongs to a typical American family. This movie portraits the differences between the two cultures in terms of traditions, food, behavior and so on. In particular, this movie served as the platform to introduce the participants to subsequent discussions regarding similar topics, but now comparing the foreign culture with Colombian culture.

Role-plays: In this kind of activities the participants had to act out a specific cultural practice from an English speaking country. To do so they used special costumes, food, posters, pictures, etc. It made them change their habitual ways of behaving so as to be able to interact socially in situations they did not normally come into contact with, but that they would probably face in the future. Here, what the participants had to do was to first select a cultural issue from an English speaking country that was of interest to them; then, they had to research about it and finally role-play the situation, turning the classroom into a foreign context. While they were role-playing information about a specific cultural issue was provided and the audience was prepared for a subsequent discussion.

Explicit discussions on cultural issues: This type of activity was the complement to the role-plays. After having received some information about a specific cultural issue, the participants were willing to express their opinions, ideas and reactions. They mostly concentrated on comparing a particular issue with the knowledge they had about the local culture. In many cases during the discussions, the participants based their comments on previous experiences they had had.

\section{Results}

In this section I present the results of the analysis carried out on the data collected throughout the research project by means of a questionnaire $(\mathrm{QU})$, reflective journals (RJ), and an interview (INT) carried out with each participant. It is important to point out that this study was aimed at exploring intercultural understanding of a group of adult EFL Colombian learners towards the culture of English speaking countries (C2).

Triangulation and validation of data were at the core of this study. The first instrument I implemented was the questionnaire; the data collected through it were compared with the data resulting from the journals. At the same time, 
the data collected by means of the journals and the videotapes were used to formulate individual questions for the interview. Finally, the interview was used to bring together more impressions of the participants, as well as to member check some of my preliminary interpretations and to dig into previous comments made by the students (see appendix 4). Color coding was my first method to start classifying and analyzing the data and by using the grounded approach I could come up with the final five categories of this study.

In general terms, I found that there were some important commonalities among the participants. For example, I found that the participants in this study started with very general and superficial concepts or insights about the foreign culture such as Americans' materialism and English's punctuality. However, throughout this research project, considering the fact that students at the end of the project expressed more aware ideas of the English speaking countries such as the acknowledgement of the existence of indigenous groups in Australia or the importance of taking a bottle of wine to a dinner party in the US, I can say that they developed a deeper level of understanding, and tolerance towards the C2. The above is evidenced in the data collected and can be better explained by looking at the categories.

\section{Stereotypes towards the target culture}

In general, I was able to identify that the students' perceptions towards the English speaking countries before my intervention were chiefly conditioned by stereotypes they had. As explained by Kramsch (1998) and Samacá (2002) the results from the questionnaire, which was the instrument designed to gather their initial impressions of the $\mathrm{C} 2$, showed that the participants had an oversimplified vision of the culture of English speaking countries because they built an image of the foreign culture from their own vision of the world. This oversimplification was first evidenced by the fact that the majority of participants only referred to USA and England when talking about English speaking cultures. Other examples of stereotypes are consumerism, family, organization, materialism and social relationships

\section{- Consumerism, family relationships and organization,}

A common opinion regarding these aspects was that people in the foreign culture were characterized by their consumerism, liberalism, their customs, their religion, music, history and family relationships and observed the differences in these aspects compared to Colombian culture. The participants saw that in 
the target culture people had no time to share with their family because they were too busy to do so. Furthermore, they had the perception that business in the $\mathrm{C} 2$ was paramount; consequently they viewed this phenomenon as opposed to what happens in Colombian culture. The students stated that Colombians had their family as a priority; while in the $\mathrm{C} 2$ this was not the case. In the next two extracts $L O$ and $O Q$ highlighted what for them made Colombian culture different from the $\mathrm{C} 2$.

"For us is important the family and the values, the honesty, the responsibility, the confident. We prefer to be together and share with others". (LO/QU)

"One Colombian cultural feature that makes it different from other cultures is the confidence and that we like (to) help the other people and we believe in the value in the family" (OQ/QU).

When referring to positive features of the $\mathrm{C} 2$, the participants maintained a stereotyped vision. They included things like punctuality as a symbol of respect and organization, better standards of living, and the free access to education as well as the importance given to education and science which are very common ideas people usually have, particularly about American and British people. In general, when they were asked about the things they liked and disliked about the foreign culture, they said things like the following,

"I know how rigorous English people are to handle time. They are extremely methodical and rigid in their personal relations".

"These countries give major possibilities to access education and a better quality of living than our countries"

\section{- Materialism and social relationships}

The most commonly mentioned negative aspect of the L2 culture was materialism. Participants thought that people in the $\mathrm{C} 2$ worried too much about money and time and, as a result, the family was overlooked and, consequently, problems like drug addiction resulted from this lack of family union. In addition, they mentioned that in the L2 culture, people were cold and not very helpful to those who did not speak English. In the following extracts from the questionnaire we can see that LE highlights the fact that social relationships are different in different countries according to his friends' experiences. Besides, LU compares the quality of those social relationships and $O Q$ expressed her disagreement with the fact of giving too much importance to money.

some friends have been living in this (these) countries for many years and they haven't been able to accommodate because they will be always foreign. In these countries 
the relations are different, maybe they are practice (practical) and cold. For example in USA the distance is very long and the people don't have many (much) time to pass (spend) together" (LE/QU)

"They are not as warm in their interpersonal relationships as Colombians are"

To sum up, this category has dealt with the fact that at the beginning, the participants of this study had an oversimplified vision of the C2. They clearly exemplified Samacá and Kramsch's ideas of how stereotypes are the product of our own culture and environment, which condition us to see the others.

\section{Differences in cultural practices}

Most of the participants said they had noticed that there were certain specific cultural practices which were quite dissimilar from culture to culture and which at some point created culture shock if people did not know about them. In this aspect, according to Savignon \& Sysoyev (2002) successful intercultural communication takes place only when learners assume their roles as openminded representatives of their L1 and as subjects engaged in a dialog of cultures. One example was SA who let us see that she was adopting openminded attitudes towards the $\mathrm{C} 2$ when she realized that things changed from culture to culture. She said,

"I enjoyed learning many different things. From just one culture, it's amazing the number of different beliefs". (SA/RJ)

\section{- Social behavior and food}

Besides gaining knowledge about different cultural practices, other participants saw how for them it was necessary to bridge these cultural gaps. LE, for example, who had traveled to Canada, to Germany and who was planning to go to Australia, described his experience in Canada with regards to cultural practices. He stated that when he was there, he was shocked by certain practices related to rules and social behavior and he noted that some Colombians behaved over-familiarly, just like they did in Colombia. Besides, he said that he realized the importance of these cultural aspects and researched about them particularly in relation to Australia, which was the country he was planning to visit. In reply to a question about his cultural experiences when he traveled to Canada, he observed,

"Mainly what had to do with rules... certain little things about what to do and what not

to do. It is like one had to prevent too much. For instance, at dinner time, that's why I 
liked what we did about food.. one felt uncomfortable because I did not know... well I can sit like this, May I ask or not?... Would it be ok? Many Colombians behaved over familiarly. For example, they went to the kitchen and did some things there and then the Canadian like did not accepted it." (LE/INT/5,6)

Another participant stated that for her, culture shock was a phenomenon that happened everywhere and that one of the most serious shocks was food. For her it might be hard to get used to differences in food. As a result, she said she felt reluctant to face this kind of situation alone because she knew that it was going to be something very different from her culture. As she observes,

"In cultural terms, I think we can have culture shock everywhere... I think that the hardest thing for one to go to another place is the food. I think it is very complicated for a person to get used to the food of other places" (OQ/INT/15)

In other reflections, some participants like $S A$ and $O Q$ frequently expressed an understanding of cultural difference stating things like,

They (The English) have special traditions that make their culture an exclusive culture.

(SA/RJ)

Monarchy topic is hard and very different from our government system, the monarchy

is interesting because it incorporates culture, laws etiquette and life styles. (LO/RJ)

In these opinions we can see how $S A$ and $O Q$ understood how special features from different cultures become distinctive factors that make a given culture exclusive. Those factors were mainly related to celebrations, the ways of government and some cultural practices, which may vary a lot from culture to culture.

\section{Positive Attitudes towards the C2}

Brown's (1994) idea of adopting a positive and open-minded attitude towards cross-cultural differences in an attempt to understand the foreign culture was evidenced here. By knowing more about the other culture the participants were able to notice new things about the $\mathrm{C} 2$ and reacted positively towards them. The participants stated that in general terms the knowledge resulting from their contact with the $\mathrm{C} 2$, had made them aware of the fact that there are other people who act and think differently. They claimed to have clarified their initial insights and in some cases they mentioned that they had changed some of the ideas they had towards the $\mathrm{C} 2$ before they participated in this project. 
SA was one of the participants who said that it was very important to try to understand other cultures. She supported her idea by saying that we are not alone in this world. In her view, there are more people who should know us as we should know them in a better way so that we can see that maybe they are not as good or as bad as the stereotype had led us to think. In SA's own words, in reply to a question about the ways she saw the things done in the project such as the role-plays, the presentations and the discussions might relate our own context,

\footnotetext{
"For me it is very important because we are not alone in this world, so others should also know about us and we about them, yeah I think it is important... and this thing of the stereotype is also very important. We can realize that things are not as bad or as good as they seem to be..." (SA/INT/27,28)

It's very important to know about other cultures because we live in a world full of different cultures and traditions, and it should help us for being aware of our own culture" (SA/RJ)
}

$O Q$ is another participant who said that she had realized about the fact that in other places there are certain behaviors, which to Colombians seem strange but for the people concerned are normal. She also acknowledged the fact that not everybody behaves in the same way, as she tended to think before, with regards to rules and ways of behavior. Like Cortazzi \& Jin (1999) who present their conception of culture as a framework of assumptions, ideas and beliefs to interpret other people's actions, words and thinking, she had the tendency to accommodate foreign cultural practices into her own framework. In her words,

\footnotetext{
"I did not thing that customs were that radical with certain things. For example, law and customs are like very crucial for them (Australia and Canada)... one always thinks that the whole world is like we behave here. Here is where we can have problems... or bother other people" (OQ/INT/11)

It's surprising to see people do things that for others are almost impossible. (OQ/RJ)
}

Some of the participants who said that they had started to become more open minded and who felt interested in and showed tolerance towards the C2 were LE, LO and HL. For LE, having received information about the ways in which business works, motivated him to become more informed about it. For LO, the experience we had in this project was the reason to start inquiring about Australian culture and building an image of this culture to prepare for a future trip or to fulfill a dream she had. LO specifically referred to the issue of 
punctuality. She thought that people in the foreign culture were strict with time. Although different from Colombia, this was something quite positive, since punctuality was tied to the idea of respect and time management. For HL it was very important to try to understand the other, to see the differences we might have with the others positively and to be open-minded to "new" things. In general terms, these participants expressed their interest about being openminded towards the $\mathrm{C} 2$. Besides, they recognized some positive aspects, as can be seen in comments below.

\title{
- Expressing interest,
}

Most participants in this study felt attracted at some point to some of the things they knew about the foreign culture and said they would like to find out more about them. In other cases, they found that they identified with some of the characteristics of the $\mathrm{C} 2$. As a result, they felt more attracted to those aspects and started to inquire more about them. As LE observes,

\begin{abstract}
"Something that I liked very much and now I am investigating is that part of the investments. It gave me more curiosity about these kinds of things. I think that the executive part that one group mentioned was very interesting. The importance of being punctual and how to do business..."(LE/INT/20)
\end{abstract}

Here LE acknowledges that there are some commercial issues specially in terms of investment and purchasing. He was interested in these aspects as he wanted to know how to invest his money properly. Consequently, what he found out in the discussion about business in USA was the starting point to continue finding out more about this topic, and possibly changing his way of investing or saving his money. As he says,

I have always wanted to go to Australia. it's an interesting country. l'd like to work and study there. it's so interesting to know about Australian culture 'cause someday I can go there. (LO/RJ)

LO, and in other comments also LE, expressed their interest in being more informed specially about Australia, since for them this was one of the most attractive countries to visit. They have become conscious about the importance of knowing about cultural elements before traveling, in order to be prepared to interact in that cultural context.

\section{- Being open minded}

All people have different things. It does not have to be judged... because I think that a human being has to be well educated apart from speaking well, in that case we 
have to try not to shock... one can try and accept but we have to be open to try new things...(HI/INT/9)

Here HL is highlighting the importance of being willing to accept new things. She sees it as an opportunity a person has to grow and innovate. Besides that, referring to the fact that in Canada when getting married it is customary to have in the wedding celebration one of the couple's closest friends disguised as a fisherman who passes around inviting the guests either to kiss him/her or the raw fish s/he is holding; $O Q$ stated that although she would probably not agree to kiss a raw fish, she understood that it was important to get used to this cultural practice.

"If I had to kiss a raw fish I probably wouldn't do it but I think that in the life all is customs". (OQ/RJ)

\section{Widened Visions and Insights of the C2.}

The participants in this study said that they had expanded the knowledge they had about English speaking countries in several aspects. For example, one participant said that in the discussions held in class she found out that in Canada English is spoken. Another participant expressed his surprise to discover that in Australia there are also certain indigenous groups, as in Colombia. The majority of the students also highlighted the fact that they had increased their knowledge about some issues of the English speaking countries. They said that the knowledge they previously had did not go beyond knowing the name of the capital and the currency of some countries. In other words, by means of using some of the different pedagogical activities that can be used to develop intercultural competence proposed by Byram (1998), the students were able to understand how different languages express different cultures. Besides, the importance of becoming "intercultural speakers" as explained by Roberts et al and Kramsch (2002) is highlighted.

In many cases the students felt surprised to learn that the conception they had of some English speaking countries was very narrow. For instance, LE's knowledge about Australia did not go beyond knowing that it was an academic place. Then, by researching he found out many new things. For example, he found that there are some indigenous groups, that barbecues are very typical there and other things he had not imagined. As he observes,

" ... I only had the image of the university, to succeed there, to work there... but I did not know what familiar structures they had or what identity... for example, I did not even 
imagine that part of the typical food or the indigenous groups... but now I see that they do have for instance the national day, that they have typic (LE/INT/ 13.5)

al food, that we have to take wine to a celebration, I did not imagine that"

Besides LE, AN and OQ also recognized that it was important to find out about these kinds of things, since they helped them become informed, not only with the language but with the foreign culture too. There were some things they had not even imagined that they had learned and that they would probably use if they happen to travel abroad. In their own words,

"By doing these kinds of activities I can first get more familiar with the English language and have a little knowledge about these cultures... perhaps someday I travel to the US and now I have an idea of how people are... it is something we accumulate and I do not know when I have the chance to travel to one place of these countries..."(AN/ INT/24,25)

If I can know the tastes of the other country, I can be able to behave in any place and to decide what I like and I don't like. (OQ/RJ)

In the same line of thought, LO highlighted the fact that with this project she had had the chance to go beyond the vague knowledge we usually have about other countries. She pointed out that there were some key or interesting cultural aspects we often overlook and that now she feels more prepared to go to an English speaking country. In other words, she felt she had enriched her previous knowledge, as she acknowledges in the following reflection,

"We know very vague things about these countries and with these presentations we had the chance to know more details that are important but that sometimes we do not pay attention to I think I widened plenty of concepts and maybe now I have more tools for the moment to go and know what I can and cannot do regarding certain things." (LO/INT/11)

$\mathrm{OQ}$ and $\mathrm{HL}$ felt more interested in cultural practices related to social behavior. For them it was interesting to know that people, in Australia for example, were more restricted than in Colombia, in the sense that they cannot sell food or drink on the streets, and there are some places they cannot smoke and so on. $\mathrm{OQ}$ said that for her it was surprising to know that people from the $\mathrm{C} 2$ were not as liberated as she thought they were. In other words, she felt surprised to know that what she thought she knew was not true. Besides talking about these cultural restrictions, HL also mentioned the significance of knowing about them to be prepared for traveling or for sharing this knowledge with her family, friends or acquaintances. She noted, 
"With regard to the fact that they do not allow their children to go out without permission, I never thought they would do that in a country like that, where teenagers are supposed to be much more rebel than here, where they have more freedom. But the fact that they have a restriction?.. it was surprising, I was shocked about that part of the laws... in general one sees the United States like everyone does what s/he wants the way they want but I realized that in those two countries (Australia and Canada) they don't, and in fact, I liked it" (OQ/INT/29)

We can see how $O Q$ has changed her vision of the way kids behave in Canada and Australia. She realized that the idea of rebelliousness and liberation she had was not as accurate as she thought. With regard to the importance of being knowledgeable with the cultural practices about social interaction, HL said,

"Well, I learned. About Australia I know it is a developed country and all that. But now I see that people cannot throw garbage, that they cannot sell things on the street, those things are like very particular, so I think that every country has its own customs. In fact that is a good thing in case of traveling someday..."(HL/INT/16)

"If someday I travel to Australia, I know how people are". (HL/RJ)

Another aspect that shows that the learners enriched their visions towards the target culture has to do with strictness and individuality, which for them constituted key features of the C2. Some of the participants' most frequent ideas about people from English speaking countries are that they are strict and that there is a tendency for people to be rather individualistic. In this regard, $\mathrm{SA}$ expresses her perceptions in the following fashion,

"Yeah, I mean, from the reading I showed to you about the American culture I know that the values are more for them to do what they want to do and not to stop thinking about they themselves to take care of the other. It is like being and doing what they want, so I think they are individualistic..."(SA/INT/12)

This quotation illustrates how this participant, who has not traveled to any English speaking country, has constructed an image of American culture based mainly on a reading about this culture. In particular, she thinks that in the $\mathrm{C} 2$ people respect each other but do not care too much about the people they come into contact with.

This category has shown how the learners gained some knowledge about how the target culture works. Here, they have expressed their opinions about the ways their initial impressions or insights about the $\mathrm{C} 2$ changed due to the fact that they realized that their initial conceptions of the $\mathrm{C} 2$ were, in many cases, not accurate. 


\section{Feelings of Preference}

Above and beyond finding out that the students had broadened their horizons in terms of cultural understanding, I was also able to identify that when they knew more things about the foreign culture they started to make connections with their own cultural visions. In some cases, they related some of the aspects of the C2 to their own cultural identity according to their interests. In other cases, they developed a desire to change some cultural things of their own culture that they had found were not as good as they were in other cultures. When the students came into contact with information about different cultural practices they identified some positive aspects in the C2 that enhanced social relationships in some cases and standards of living in others. In this aspect, Kramsch's (1998) idea of change in the individuals' identity due to time and dialog with others is evidenced. Throughout the project the participants were able to discover that some cultural practices of the $\mathrm{C} 2$ were worthwhile.

\section{- Time matters}

Aspects related to time were the most mentioned when referring to a $\mathrm{C} 2$ positive cultural practice. Some students recognized the importance of handling the time efficiently. In the following extract we can see how the participant was willing to change some aspects of her behavior. She acknowledged that she would like to manage time in a better way because she sees that being punctual is a way of not wasting time and doing things at the right moment.

\footnotetext{
"I think that being punctual is very good. It is good not to waste time, although here we keep on doing so... of course we can get to the against the clock culture in which we are trying to do things on time and one is all the time running and doing and not wasting time, I think it's good not to waste time..."(SA/INT/17)
}

In the same line of thought, $\mathrm{LU}$ sees how here in Colombia the issue of time is really serious. She has experienced situations in which time is so badly administered that the original objectives of a meeting can be changed by other superficial or different things not related to the main aims of the meeting. As a result of this, the most common solution is to procrastinate. As she observes,

"Here we waste much time. Many times one goes to a meeting and people start talking about things that are not even related to the topic, so I end up exhausted and saying oh no, no we don't have enough time, let's leave this for the next meeting. Yeah many times we don't go straight to the point..."(LU/INT/43) 


\section{- Social rules}

Some social patterns students got to know were perceived as appropriate. LU and $\mathrm{HL}$ also agreed with some of the laws that regulate alcohol use or street sales in Australia. For example, they think that it would be a great idea to have those rules in Colombia too, since those would help to reduce street fights and would improve the organization of the streets.

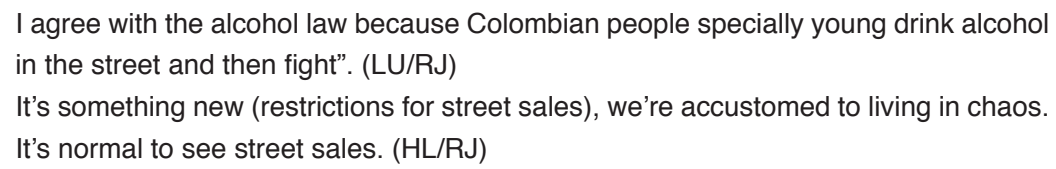

All in all, this study has shown that the adults EFL learners, who participated in this project, had a narrow vision of the target culture. At the beginning the insights they had about the English speaking countries were framed by stereotypes. As the project progressed the participants started to expand their initial visions and started to notice that there were some cultural differences between their own Colombian culture and the target one. As a result, they started to become more conscious about the $\mathrm{C} 2$. In this process of developing awareness they also became more interested and tolerant. Moreover, they showed that the cultural knowledge they gained during the project helped them to better understand cultural practices of the target culture in such a way that on occasions they even felt inclined to adopt some of the foreign behaviors which resulted very positive and appealing to them.

\section{Conclusions}

Bearing in mind that this study was aimed at exploring cultural understanding of English speaking countries, the participants completed a series of tasks that helped them broaden their horizons from an intercultural perspective. In general terms, the participants researched and explored some features of the C2 and later contrasted and compared them with their own socio-cultural contexts. As a result, and considering the theoretical support, the goals and the findings in this study, we can conclude that:

- Usually, when an adult EFL learner is not exposed to cultural knowledge or contact with the target culture, this learner creates an image of the foreign culture that, in many cases does not go beyond a superficial stereotype. In some cases, the learner tends to over generalize from what he hears or sees 
in the mass media. In other cases, as Cortazzi and Jin (1999) have explained in relation to studies carried out with regards to the relationships between language teaching and intercultural competence, if the learner is not conscious about other frameworks of perceiving ideas, ways of behaving and thinking, the learner tries to accommodate the foreign socio-cultural reality within his own socio-cultural framework or vision of the world. This happened to some of the participants who said that they thought that in other countries people did things the way we do in Colombia. In other words, they tried to over generalize the vision of the world they had by wrongly extending their cultural framework to other cultures without considering differences.

- The narrow or superficial vision the adult EFL learner often has about the foreign culture can be broadened. By having the learners become acquainted with more knowledge about how things work in the foreign context, the learner starts to realize that there are many differences as well as similarities that go beyond the stereotyped vision we usually have. By doing this the learner sees that there are some important and interesting details about the $\mathrm{C} 2$ that are not well-known or which have been overlooked

- Following Gail (1995), who maintained that the EFL learners can be helped to understand a foreign culture by having them describe it instead of evaluating or judging it, by finding differences and similarities between their culture and the foreign one, the EFL learner can gather a series of characteristics that can lead the learner to become more open-minded to new and different ideas. Consequently, the EFL learner will most likely raise his/her level of awareness, tolerance and interest in the $\mathrm{C} 2$.

- In many cases, when the EFL learner tries to be informed and know more the target culture, it can be seen that $\mathrm{s} /$ he discovers some similarities and differences among the cultures involved. This acknowledgement might lead them to think that no culture is better or worse than the other but that they are just different. In other words, by helping the language learners get to know the other culture, they develop a more aware and value-balanced conception of the local culture and the target culture.

- On occasions, the EFL learner who is in a process of understanding a foreign culture can come across certain practices that affect his/her own cultural identity. As the learner discovers a culture for the first time, s/he can find positive and negative things, which are different from his/her own; in this 
kind of situations the learner is exposed to cultural knowledge and experiences that enrich his/her own cultural background.

\section{References}

Brown, D. (1994) Teaching by Principles: an Introductive Approach to Language Pedagogy. Prentice Halls Regents.

Brown, D. (2000) Principles of Language Learning and Teaching, forth edition.. Longman.

Byram, M \& Fleming (2002), M. Language Learning in Intercultural Perspective: approaches through drama and ethnography. Cambridge, Cambridge University Press.

Byram, M. and Risager, K. (2000). Language Teachers, Politics and Cultures. Clevedon: Avon: Multilingual Matters

Byram, M. (1998) Cultural Studies in Foreign Language Education. Clevedon: Multicultural Matters.

Byram, M. (1990) Foreign Language Teaching and Young People's Perceptions of Other Cultures. In: Harrison, B. Culture and the Language Classroom. Hong Kong: Modern English Publication and the British Council.

Canagarajah, S. (1999) Resisting linguistic imperialism in English teaching. Oxford:Oxford University press.

Cortazzi, M. \& Jin, L. (1999) Cultural Mirrors. In: Hinkel, E. Culture in Second Language Teaching and Learning. Cambridge University Press.

De Mejía, A.M. (2002). Power, Prestige and Bilingualism. Clevedon: Multilingual Matters.

Hopkins, D. (1995). A Teachers Guide to Classroom Research. Buckingham, Philadelphia: Open University Press.

Hubbard, R \& Miller, B. (1993) The Art of Classroom Inquiry: A handbook for teachers researchers. New Hampshire: Heinemann.

Hubbard, R \& Miller, B. (1999) Living the Question: a guide for teachers researchers. York, Maine: Stenhouse Publishers.

Kramsch, C. (1998) Language and Culture. Cambridge; CUP.

Kramsch, C (2002). The Priviledge of the Intercultural Speaker. In: Byram; M. \& Fleming, M. Language Learning in Intercultural perspective. United Kingdom. Cambridge University Press. 
Kramsch, C., Cain, A. \& Murphy, E. (1996). Why Should Language Teachers Teach Culture?. Cultural Representation in Language Learning and teaching Training. Language, Culture and Curriculum, Vol. 9:1. pp 99-107

Krashen, S. (1982). Principles and Practice in second Language Acquisition. Oxford. Pergamon.

Lankshear, C \& Knobel, M (2004) A Handbook for Teacher Research: from design to implementation. New York: Open University Press.

Nemetz, G. (1988). Cross-cultural Understanding. Great Britain. Prentice Hall International. UK Ltd.

Nunan, D. (1981). Looking at Learners, Understanding Language Classrooms. England. Prentice Hall International.

Nunan, D. (2001). Research Methods in Language Learning. USA. Cambridge University Press.

Pennycook, A. (2001). Critical applied linguistics: A critical introduction. Mahwah, NJ: Erlbaum.

Richards, J.,et al. (1999) Dictionary of Language Teaching and Applied Linguistics. Malaysia. Longman.

Roberts, C. et al. (2001) Language Learners as Ethnographers. Clevedon: Multilingual Matters.

Samacá, G. (2002) Les Français et Nous: el Estereotypo, una Fuente de Aprendizaje de la Cultura en el Aula Bilingüe. In De mejia, A \& Nieves,R. Nuevos caminos en educación bilingüe en Colombia. Universidad del valle.

Savignon, S. \& Sysoyev, P. (2002). Sociocultural Strategies for a Dialog of Cultures. The Modern Languages Journal.

Seidman, I. (1991). Interviewing as Qualitative Research. New York: Teacher College Press.

Skinner, B.F, (1953). Science and Human Behavior. New York. MacMillan.

Stevick, E. W. 1976. Memory, meaning, and method. Rowley, MA: Newbury House Publishers. 


\section{Appendix 1}

\section{Questionnaire}

El siguiente cuestionario hace parte de un proyecto de investigación que actualmente estoy adelantando. El objetivo del mismo es conocer sus opiniones acerca de aspectos culturales relacionados con el aprendizaje del inglés como idioma extranjero. Por lo tanto, es de gran importancia que las preguntas sean contestadas con la mayor sinceridad posible. La información que aquí se recoja será confidencial.

1. ¿Cuanto tiempo lleva estudiando inglés?

2. ¿Cree usted que al aprender inglés se deben tener en cuenta aspectos culturales? Si no ¿porqué?

3. ¿Qué aspectos culturales conoce de los países de habla inglesa?

4. ¿Qué le gusta de estos países en relación con las costumbres, maneras de pensar y relaciones humanas? ¿porqué?

5. ¿Qué no le gusta de estos mismos temas? ¿Porqué no?

6. ¿Qué aspectos culturales de los países de habla inglesa le gustaría conocer? (tradiciones, política, religión, tabúes, lenguaje corporal, costumbres, personas famosas, festividades, etc.) ¿por qué?

7. ¿Sabe usted qué es un choque cultural? Si no ¿qué es?

Si la respuesta a la anterior pregunta fue positiva conteste la siguiente

8. Ha tenido experiencias de choque cultural? Si no Describa una de las más significativas. Porqué cree que fue tan significativa? 
9. ¿Qué lo identifica como perteneciente a la cultura colombiana?.

10. ¿En su opinión, qué características culturales identifican a los colombianos que nos hace diferentes a los demás?

11. ¿Se siente total o parcialmente identificado con estos rasgos?. ¿Porqué? ¿Porqué no? 


\section{Appendix 2}

\section{Reflective Journal}

After the following sessions dedicated to the project, you are going to write a reflection about the cultural issues discussed. This will consist mainly of writing down your reactions, feelings, opinions, positive/ negative points, and comments about the aspects discussed in the presentation and discussion session you have participated in. In other words, you have to express your point of view in written form about the topics that have been discussed in the different sessions.

NAME: DATE:

CULTURAL THEME(S) OF THE RESENTATION:

YOUR REACTIONS TOWARDS THIS/THESE TOPIC(S):

POSITIVE POINTS ABOUT THIS/THESE TOPIC(S):

NEGATIVE POINTS ABOUT THIS/THESE TOPIC(S):

RELEVANCE OF THIS/THESE TOPICS FOR YOU:

THINGS YOU HAVE LEARNT:

ADDITIONAL COMMENTS: 


\section{Appendix 3}

\section{Interview Protocol}

The following interview aims at knowing in more detail your perceptions and insights about the ways in which you have experienced English learning. Specifically it is focused on your opinions about the relationship between language and culture based mainly on the cultural issues discussed in class. If at any point you feel uncomfortable or confused with the questions, do not doubt to ask for clarification.

1. What has your experience of learning English been like?

- Why are you studying it?

- How do you feel with what you have learned so far?

- What has been difficult for you in your learning process?

- What is missing to reach your goal with English?

2. In your process, have you learned cultural aspects? which ones?

- How have you learned them?

- Have them been useful for you? Why? Why not?

3. Have you traveled to an English speaking country

- How was your experience there?

- Did you have any difficulty?

- Do you think cultural learning is important in language learning? Why? Why not?

- Did you learn anything in regards to culture, there?

4. Has your knowledge of culture changed through the sessions held in class? Why? Why not?

- Has the process carried out in these sessions been relevant for you? Why? Why not?

- Do you think you are prepared to travel to an English speaking country? Why? Why not? 


\section{Appendix 4}

Sample of individual questions for the interview taken from the data gathered mainly by means of the videotapes and less frequently from data gathered through the other instruments.

\section{Participant: HI}

In the class discussion about the ways in which Americans do business you said "It is good to know how business is done in different cultures to be safe". Would you mind elaborating more on that?

From your reflection and comparison between Colombia and Australia you said that we live in chaos. Why do you think so?

In the reflective journal you said "we should know about other behaviors in different situations". Could you please explain what you meant by that?

In the discussion about monarchy and etiquette in England you said "it's like another world". Could you elaborate a bit more on that?

In the second entry of the reflective journal you said that in order to know more about a foreign culture "Reading is good, traveling too". How have you experienced this process of reading to learn cultural topics?

In the third class discussion you said "I am aware of the different types of life of other people", but how important is for you to know details about these differences?

In the discussion about cultural issues in Canada you said that the presentation was relevant for you because when you travel there you will have more cultural knowledge but you only mentioned the fact that there mainly English and French are spoken. Is there anything else of interest for you?

\section{THE AUTHOR}

Ferney Cruz Arcila holds an MA degree in Applied Linguistics from Universidad Distrital. He also holds an undergraduate degree from Pedagógica Nacional and he is currently participating in the VIF program. He has previously worked at Universidad Militar Nueva Granada and at Universidad Pedagógica Nacional de Colombia.

E mail: cruzferney@yahoo.com 